\title{
Operating budget practices in the US club industry: $A$ comparative study, 1986-2006
}

Received (in revised form): 25 April 2007

\section{Raymond S. Schmidgall}

is the Hilton Hotels Professor of Financial Management at Michigan State University. He is the author of "Hospitality Industry Financial Accounting, Managerial Accounting for the Hospitality Industry'. He serves in the industry committees of the Hospitality Financial and Technology Professionals and the American Hotel and Lodging Association.

\section{Arjun J. Singh}

is an associate professor in The School of Hospitality Business at Michigan State University. Dr Singh's research and teaching interests focus on International Lodging, Finance and Real Estate. Dr Singh's hospitality experience includes various management positions, educational assignments and consulting practices in the USA, India, China and Europe.

\begin{abstract}
A key financial yardstick to measure operating performance is a statement of forecasted revenues and expenses, captured in the operating budget of a hospitality business. Club Managers prepare operating budgets as part of their forecasting and planning exercise. The preparation process and practices of operations budgeting in the US club industry was virtually unknown in the mid-1980s. Starting with the initial research in 1986 , this paper attempts to compare changes in practice of preparing operating budgets in the US club industry over the last 30 years.
\end{abstract}

\section{Keywords:}

budget, club industry, financial management, club operations, performance benchmark

Journal of Retail and Leisure Property (2007) 6, 231-238.

doi:10.1057/palgrave.rlp.5100060

Raymond S. Schmidgall The School of Hospitality Business 232 Eppley Center Michigan State University East Lansing

Michigan 48824, USA

Tel: +1 (517) 3539211

Fax: +1 (517) 4321170

E-mail: schmidga@msu.edu

\section{INTRODUCTION}

Planning is an important management function in a social club and involves setting measurable and realistic goals and objectives. A critical planning function involves the creation of a financial budget, which often involves several members of the executive management team. The budget process results in at least three separate budgets. The operating budget reflects forecasted revenues and expenses. The cash budget reveals expected cash receipts and disbursement. The capital budget includes the projects, such as the purchase of equipment, to be undertaken over the next year. 
Textbooks exist to assist managers in the hospitality industry in preparing operating budgets. ${ }^{1,2}$ Furthermore, Schmidgall has written a textbook, to specifically address the preparation of operating budgets in clubs as well as several other factors regarding operating and other types of budgets. ${ }^{3}$ In addition, Club Management in its Guidelines for Club Administration discusses the advisory role of the budget and finance committee regarding the presentation of the operating budget to the club's board. ${ }^{4}$

From a research perspective many questions regarding the operating budgeting practices in the club industry were, however, historically underinvestigated. These questions included the process of developing operations budgets, the purpose of these budgets, primary financial goal, tentative financial goals and revision of operating budgets. In an attempt to address these questions, Schmidgall conducted a survey of US club managers in 1986 and replicated the same study in $1996.5,6$

The chief findings of the 1996 study were as follows:

(1) The preparation of operating budgets is a joint effort of the general manager (GM), department heads and others.

(2) The major reason the operations budget is prepared is to serve as a standard of comparison.

(3) A majority of club executives set tentative financial goals prior to preparing the clubs' operating budgets.

(4) The most common financial goal was the club's bottom line on its statement of operations.

(5) About one in three clubs prepare long-range operating budgets covering two or more years.

(6) Nearly one in three clubs revise their operating budgets during the year generally when the club performance indicates a revision is necessary.

The present study, conducted in 2006, was undertaken to determine the operating budget preparation practices of US clubs in the first decade of the 21 st century and analyse changes in budgeting practices from the two previous decades.

\section{METHODOLOGY}

In order to obtain answers to the several clubs' operating budget practices, an extensive mail questionnaire was prepared and sent to 3,000 members of the Club Managers Association of America (CMAA). The vast majority of members are GMs of social clubs in the United States. As GMs, they answer to their governing boards for the operating budgets of the clubs they manage. Therefore, they are generally the most knowledgeable executives regarding their clubs' operating budgeting practices.

Responses received were processed using SPSS. Frequencies and cross-tabulations based on relevant demographic factors are analysed and presented. 


\section{RESPONDENT PROFILE}

Six hundred and twenty-three (20.8 per cent) of the 3,000 members of CMAA who were mailed the questionnaire responded. Table 1 contains the details of respondents and their clubs. Nearly 90 per cent of the respondents were GMs while 7 per cent were club managers. Other titles of respondents included assistant manager, club accountant, controller, chief operating officer and chief financial officer. All respondents appear to occupy positions that would enable them to be knowledgeable regarding the operating budget practices of the clubs employing them. Therefore, we believe that their responses reflect operating budget preparation practices of their clubs. Nearly 80 per cent of the respondents are employed by country clubs. Other respondents work for city, golf, yacht, tennis, university, beach and equestrian clubs.

The size of clubs of respondents were measured by both number of members and annual revenues. The largest group of club executives are

Table I: Demographics of respondents and their clubs

\begin{tabular}{|c|c|c|}
\hline & $N$ & (\%) \\
\hline \multicolumn{3}{|l|}{ (A) Title of respondents } \\
\hline General manager & 542 & 87 \\
\hline Club manager & 42 & 7 \\
\hline Assistant manager & 2 & 0 \\
\hline Other & 37 & 6 \\
\hline Total & 623 & 100 \\
\hline \multicolumn{3}{|l|}{ (B) Type of club } \\
\hline Country & 485 & 78 \\
\hline City & 52 & 8 \\
\hline Golf & 31 & 5 \\
\hline Yacht & 28 & 5 \\
\hline Other & 27 & 4 \\
\hline Total & 623 & 100 \\
\hline \multicolumn{3}{|c|}{ (C) Size of club - gross revenues including dues (000's) } \\
\hline$<\$ 1,000$ & 14 & 2 \\
\hline $1,000-2,000$ & 63 & 10 \\
\hline $2,001-3,000$ & 97 & 16 \\
\hline $3,001-5,000$ & 231 & 37 \\
\hline $5,001-10,000$ & 175 & 28 \\
\hline 10,000 & 41 & 7 \\
\hline No response & 2 & 0 \\
\hline Total & 623 & 100 \\
\hline \multicolumn{3}{|c|}{ (D) Size of club - number of members } \\
\hline$<250$ & 27 & 4 \\
\hline $250-500$ & 227 & 37 \\
\hline $50 \mathrm{I}-750$ & 193 & 31 \\
\hline $751-1,000$ & 75 & 12 \\
\hline $\mathrm{I}, 00 \mathrm{I}-2,000$ & 79 & 13 \\
\hline$>2,000$ & 21 & 3 \\
\hline No response & 1 & 0 \\
\hline Total & 623 & 100 \\
\hline \multicolumn{3}{|c|}{ (E) Profitability of club (Food \& beverage profits/Food \& beverage sales) } \\
\hline$<-5 \%$ & 197 & 32 \\
\hline$-5 \%$ to 0 & 128 & 20 \\
\hline 0 to $5 \%$ & 103 & 17 \\
\hline$>5 \%$ & 169 & 27 \\
\hline No response & 26 & 4 \\
\hline Total & 623 & 100 \\
\hline
\end{tabular}


employed by clubs with annual revenues of $\$ 3$ to $\$ 5 \mathrm{~m}$, followed by clubs with annual revenues of $\$ 5$ to $\$ 10 \mathrm{~m}$. Member-wise, the largest group of respondents work for clubs with 250-500 members (37 per cent), followed by clubs with 501-750 members ( 31 per cent). Table 1 contains additional details regarding the size of clubs of respondents.

The final demographic measure was profitability of club food and beverage departments. Thirty-two per cent of the respondents' clubs reported food and beverage departmental losses of greater than 5 per cent, while at the other extreme 27 per cent reported profits greater than 5 per cent. The median club's food and beverage profits were zero as shown in Table 1, while 52 per cent clubs of respondents have either a breakeven or losing money operating their food and beverage departments.

\section{ANALYSIS OF RESULTS}

The findings of this latest research is presented in this section and comparisons are made to the previously mentioned research of clubs' operating budgeting practices conducted by Schmidgall in both the 1980s and 1990s.

First, the operations budget is developed by a team of club executives and often committee heads in over 90 per cent of the responding clubs. The GM prepares it with little input from others at 9 per cent of the clubs. Greater input is provided by a team approach than when a single person prepares the operations budget without major input from others. The makeup of the executive team varies considerably as shown in Table 2.

For comparison purposes, the results of the 1996 study are also shown in Table 2. There is little difference in how the operations budgets are being prepared in this decade compared to 2006. By comparison, the 1985 study revealed that 86 per cent of the GMs prepared their operating budgets with input from others, while 12 per cent of the GMs prepare the operations budget virtually alone, that is, with little input from others. The 1985 study did not provide the details of the two more recent studies. Thus, there is a slight movement over the past three decades from 12 per cent of the GMs preparing the operations budget alone in the 1980s to 12 per cent in the 1990s, and now to 9 per cent during the first decade of the 2000s.

Table 2: Approach to preparing operating budgets

\begin{tabular}{|c|c|c|c|}
\hline & \multicolumn{2}{|c|}{2006 Study } & \multirow[t]{2}{*}{1996 Study (\%) } \\
\hline & $\mathbf{N}$ & $(\%)$ & \\
\hline GM and accounting department head prepare it together & 81 & 13 & 15 \\
\hline $\begin{array}{l}\text { GM with department heads and committee heads prepare } \\
\text { it together }\end{array}$ & 300 & 49 & 52 \\
\hline $\begin{array}{l}\text { Accounting department head prepares it with input from } \\
\text { other department heads, committee heads and the GM }\end{array}$ & 100 & 16 & 13 \\
\hline GM prepares it with input from department heads & 25 & 4 & - \\
\hline Other teams prepare it & 52 & 9 & 8 \\
\hline GM prepares it with little input from others & 58 & 9 & 12 \\
\hline Total & 616 & 100 & 100 \\
\hline
\end{tabular}


Table 3: Major reasons for the operating budgeting

\begin{tabular}{llll}
\hline & 1985 (\%) & $1996(\%)$ & 2006 (\%) \\
\hline Standard of comparison & 42 & 56 & 60 \\
Planning tool & 43 & 37 & 32 \\
Other (including Board of Directors & 15 & 7 & 8 \\
or Bylaw Requirement) & & & \\
\hline
\end{tabular}

The primary reason for preparing an operating budget is for comparison purposes. Generally after the end of the month, the actual results are compared to the budgeted results and significant differences are analysed enabling management to take action. In addition, for many clubs the major reason for preparing this budget is planning purposes. Table 3 indicates the major reason respondents indicated for preparing the operating budget and shows a clear trend towards standard of comparison as the major reason the operating budget is prepared. In the 1980s, it was a virtual toss-up between 'planning tool' and 'standard of comparison'; however, the most recent survey clearly shows by nearly a two-to-one margin that the operations budget is prepared by an increasing majority so that it can be used as a standard of comparison. Nearly, one of every twelve respondents indicated that there are multiple reasons for preparing the operating budget for their club. The analysis of these returns suggests that both standard of comparison and planning tool are most important followed by either or both board of directors and bylaws that require it.

Club executives were asked if a tentative financial goal was established prior to developing the operations budget, and if so, 'what is it based on?' Forty-eight per cent of the respondents in this study indicated that a tentative financial goal was established compared to 57 per cent from the 1985 study and 46 per cent from the 1996 study. Thus, there has been some change in the past ten years. The tentative financial goals set by clubs over the three studies have changed as shown in Table 4 and suggest a slight refocus on the bottom line as 76 per cent of the respondents indicate this is the tentative financial goal compared to 70 per cent in 1996 and 79 per cent in the 1985 study. The focus on sales as a financial barometer has declined from 18 per cent in the 1985 study to only 6 per cent in this study. The 'other' goal has increased over the studies to 18 per cent in this study. Other in this study includes many different factors such as 'cash breakeven,' 'gross operating profit,' 'money in the bank' and 'amount to satisfy debt service.' In addition, several respondents indicated multiple financial goals in this study, such as 'net income and sales,' 'revenues and cash flows' and 'sales and operating expenses.' Clearly, it appears that clubs are becoming more financially sophisticated with the establishment of multiple financial goals in this study compared to virtually none being mentioned in the two prior studies.

Operating budgets may be prepared for short (one year or less) and long periods of time (more than one year). The most common is the annual budget that results from adding 12 monthly budgets together. Historically, a number of clubs, however, have, prepared operating budgets for several years into the future. Just over 31 per cent of 
Table 4: Tentative financial goals

\begin{tabular}{lccc}
\hline & $1985(\%)$ & $1996(\%)$ & $2006(\%)$ \\
\hline The bottom line & $79 \%$ & $70 \%$ & $76 \%$ \\
Sales & 18 & 17 & 6 \\
Other & 3 & 13 & 18 \\
Total & $100 \%$ & $100 \%$ & $100 \%$ \\
\hline
\end{tabular}

Table 5: Length of long range operating budgets

\begin{tabular}{llll}
\hline Number of years & $1985(\%)$ & $1996(\%)$ & $\mathbf{2 0 0 6}(\%)$ \\
\hline Two & $21 \%$ & $10 \%$ & $16 \%$ \\
Three & 24 & 37 & 27 \\
Five & 47 & 49 & 50 \\
Other & 8 & 4 & 7 \\
Total & $100 \%$ & $100 \%$ & $100 \%$ \\
\hline
\end{tabular}

respondents in this study indicated that they prepare long-range operating budgets. By comparison, 36 and 35 per cent of the respondents to the 1985 and 1996 studies, respectively, prepared long-range operating budgets. The length of the long-range operating budgets for this study and the two prior studies is shown in Table 5.

'Other' in Table 5 included a number of responses such as four years, seven years and even as much as ten years. Clearly, nearly half the clubs preparing a long-range operating budget do so for a period of five years. There has been some shifting between two and three years in the three studies, but when combined the differences do not appear to be major as the total for the two figures was 45 per cent in the 1985 study, increased to 47 per cent in the 1996 study and declined to 43 per cent in this latest study.

The responses (yes or no) to whether long-range operating budgets are prepared were cross-tabulated with size of club (revenue and number of members) and food and beverage profitability. Statistical differences (based on $\chi^{2}$ less than 5 per cent) were noted for the size of club based on both annual revenue and number of members. Twenty per cent of the smaller clubs (revenues of less than $\$ 2,000,000$ ) prepare long-range operating budgets while 36 per cent of the largest clubs (revenues in excess of $\$ 5,000,000$ ) prepare long-range operating budgets. Further, 24 and 34 per cent of the clubs with $\$ 2$ to $\$ 3 \mathrm{~m}$ and $\$ 3 \mathrm{~m}$ to $\$ 5 \mathrm{~m}$ annual revenues, respectively, prepare long-range operating budgets. Similar results are revealed for clubs based on the number of members as shown in Table 6. Clearly, the larger the club the more likely the long-range operating budgets are prepared.

In addition, the larger the club the greater the percentage of clubs preparing five-year operating budgets based on annual revenues and number of members as shown in Table 7. Clearly, the larger the club based on annual revenues the more likely the clubs preparing long-range budgets prepare them for five years. 
Table 6: Percentage of clubs preparing long-range operating budgets by number of members

\begin{tabular}{ll}
\hline$<500$ members & $=26$ (\% preparing long-range operating budgets) \\
$501-750$ members & $=29$ \\
$751-1,000$ members & $=39$ \\
$>1,000$ members & $=44$
\end{tabular}

Table 7: Percentage of clubs using five-year budgets

\begin{tabular}{llll}
\hline Annual revenues & (\%) & Member size & (\%) \\
\hline$<\$ 2 \mathrm{~m}$ & 40 & $<500$ & 39 \\
$\$ 2$ to $\$ 3 \mathrm{~m}$ & 48 & $501-750$ & 47 \\
$\$ 3$ to $\$ 5 \mathrm{~m}$ & 46 & $751-1,000$ & 68 \\
$>\$ 5 \mathrm{~m}$ & 55 & $>1,000$ & 56 \\
\hline
\end{tabular}

Table 8: Frequency of operating budget revisions

\begin{tabular}{lccc}
\hline & 1985 (\%) & 1996 (\%) & 2006 (\%) \\
\hline Monthly & 9 & 19 & 11 \\
Quarterly & 28 & 18 & 17 \\
Semi-annually & 23 & 20 & 18 \\
When club performance indicates a need & 37 & 36 & 44 \\
Other & 3 & 7 & 10 \\
Total & 100 & 100 & 100 \\
\hline
\end{tabular}

Through a fiscal year, various events may render the original operating budget less useful than at the beginning. For the most part, these events are external and often could hardly be predicted such as $9 / 11$ or an unusual Spring flood or a damaging hurricane. Recovery from these events may take weeks or even months rendering the budget figures as somewhat meaningless. The solution is to revise the budgets thus providing relevant budget numbers for comparison purposes.

Nearly, 28 per cent of respondents indicated they revise their club's operating budgets at some point during the year. By comparison, 33 and 47 per cent of the clubs revised their budget numbers, respectively, according to the 1996 and 1985 studies. Thus, it appears that currently, fewer clubs are revising their operating budgets as the club progresses through its fiscal year during the last two decades of the prior century.

A related question posed was, 'how often is the operating budget revision performed?' Table 8 shows the results for the three related studies. The most common frequency for revising the operations budget is when club performance indicates a need. In the past century, the two studies revealed 36-37 per cent while the most recent study showed 44 per cent of the clubs' operating budgets are revised as needed. The next two most common revision points are quarterly and semi-annually across the three studies. The other responses shown in Table 8 included 'how close the club is on dues,' 'hurricanes' impact on operations,' 'revise when 
expenses occur that were unforeseen at budgeting time' and 'reforecast at the end of the third quarter.'

\section{SUMMARY}

Operating budgets prepared by club executives result from a participatory process. Typically, the GM, accounting and other departmental heads, and committee heads are involved. The major reason for preparing the operating budget is that it serves as a standard of comparison. A second reason is for planning purposes. Over the past three decades, the emphasis has changed to focus more on operating budgets as a standard of comparison. Many clubs (48 per cent in the most recent study) have a tentative financial goal prior to starting the budgeting process. Over 75 per cent of the clubs, with a tentative financial goal, focus on the club's bottom line as its operating statement.

Fewer clubs are using long-range operating budgets than in the recent past. The most common period of time covered by these long-range budgets is five years. This time factor has changed little over the three studies discussed in this paper. Fewer clubs are revising their operating budgets during the fiscal year in this decade compared to the final two decades of the 20th century. The most common revision point has been and continues to be when club performance indicates a need.

\section{Acknowledgements}

This research was funded by The Club Foundation of the Club Managers Association of America.

\section{References}

1. Jagels, M.G. (2007). Hospitality Management Accounting, 9th edn, John Wiley \& Sons, Hoboken, NJ.

2. Schmidgall, R.S. (2006). Hospitality Industry Managerial Accounting, 6th edn, Educational Institute of the AH\&LA, Lansing, MI.

3. Schmidgall, R.S \& Damitio, J.W. (2001). Accounting for Club Operations, Educational Institute of the AH\&LA, Lansing, MI.

4. The Virtual Clubhouse. Guidelines for club administration. http://www.club.mgmt.com.

5. Schmidgall, R.S. (1986). Budgeting practices of clubs. Club Management. 65(4), 48-52.

6. Schmdigall, R.S. (1997). Operating budgets preparation. Club Management. 76(11), 38-44. 